\title{
Penggunaan UV-Vis Spektroskopi dan Kemometrika untuk Uji Keaslian Kopi Codot Lampung
}

\section{(The Use of UV-Vis Spectroscopy and Chemometrics for Authentication of Lampung Codot Coffee)}

\author{
Meinilwita Yulia ${ }^{1}$, Kurnia Rimadhanti Ningtyas ${ }^{2}$, Diding Suhandy ${ }^{3^{*}}$
}

(Diterima Januari 2021/Disetujui Mei 2021)

\begin{abstract}
ABSTRAK
Kopi Codot dari Tanggamus, Lampung merupakan salah satu kopi spesialti Indonesia dengan produksi yang sangat terbatas. Dalam penelitian ini, studi keaslian kopi bubuk Codot dilakukan dengan menggunakan UV-vis spektroskopi dan kemometrika. Sebanyak 330 sampel kopi Codot murni dan campuran disiapkan sebagai sampel. Sampel kopi Codot campuran dibuat dengan sengaja menambahkan kopi biasa (kopi bukan Codot) pada tiga level pencampuran, yaitu level rendah (10-20\%), level sedang (30-40\%), dan level tinggi (50-60\%). Semua sampel kopi bubuk berukuran $0,29 \mathrm{~mm}$. Prosedur ekstraksi dilakukan dengan air distilasi panas $\left(98^{\circ} \mathrm{C}\right)$. Data spektra setiap sampel kopi diperoleh dengan menggunakan UV-vis spektrometer tipe benchtop dalam rentang panjang gelombang 190-1100 nm menggunakan mode transmitans. Hasil penelitian menunjukkan bahwa sampel kopi Codot murni dan campuran dapat dibedakan sepanjang sumbu PC1 dan PC2. Model klasifikasi dikembangkan menggunakan metode LDA dengan akurasi $\mathbf{9 0 , 9 1 \%}$. Model LDA digunakan untuk mengklasifikasikan sampel baru dan menghasilkan sensitivitas (SEN) $100 \%$, spesifisitas (SPEC) $76,67 \%$, presisi (PREC) $78,13 \%$, dan akurasi (ACC) $87,27 \%$. Dengan menggunakan regresi PLS, model PLS dibangun untuk menghitung persentase pencampuran kopi Codot dan menghasilkan koefisien determinasi yang tinggi, baik untuk kalibrasi maupun validasi $\left(R^{2}\right.$ kal $=0,99$ dan $R^{2}$ val $\left.=0,98\right)$. Hasil ini menunjukkan UV-vis spektroskopi dan kemometrika sesuai untuk uji keaslian kopi spesialti Codot dengan RMSEP $=2,68 \%$ dan RPD prediksi sebesar 6,49.
\end{abstract}

Kata kunci: LDA, PCA, regresi PLS, uji keaslian, UV-vis spektroskopi

\section{ABSTRACT}

Codot coffee from Tanggamus, Lampung is one of Indonesian specialty coffee with a very limited production. In this research, an authentication study for the Codot ground roasted coffee was conducted using UV-vis spectroscopy and chemometrics. A total of 330 samples of pure and adulterated Codot coffee was prepared. The adulterated Codot coffee samples were intentionally created by adding a regular coffee (non-Codot coffee) into pure Codot coffee samples with three levels of adulterations: low (10-20\%), medium (30-40\%), and high level (50-60\%). All samples were $0,29 \mathrm{~mm}$ in particle size. The extraction procedure was performed with hot distilled water $\left(98^{\circ} \mathrm{C}\right)$. The spectral data of coffee samples were acquired using a benchtop UV-visible spectrometer in the range of 190-1100 nm using a transmittance mode. The result showed that the pure and adulterated samples could be discriminated along PC1 and PC2 axis. The classification model was developed using LDA with $90,91 \%$ of accuracy could be obtained. The LDA model was used to classify the new samples and resulted in a sensitivity (SEN) of $100 \%$, specificity (SPEC) of $76,67 \%$, precision (PREC) of 78,13\%, and accuracy (ACC) of $87,27 \%$ could be obtained. Using PLS regression, a PLS model was developed to quantify the percentages of Codot coffee adulteration and resulted in high of coefficient of determination both in calibration and validation $\left(R^{2}\right.$ kal $=0,99$ and $R^{2}$ val $\left.=0,98\right)$. These results showed that UV-vis spectroscopy and chemometrics are suitable for authentication of Codot specialty coffee with RMSEP $=2,68 \%$ and RPD in prediction of 6,49 .

Keywords: authentication, LDA, PCA, PLS regression, UV-vis spectroscopy

\footnotetext{
1 Program Studi Mekanisasi Pertanian, Jurusan Teknologi Pertanian, Politeknik Negeri Lampung Jl. Soekarno Hatta No.10, Rajabasa, Bandar Lampung, 35144

2 Program Studi Pengembangan Produk Agroindustri, Jurusan Teknologi Pertanian, Politeknik Negeri Lampung Jl. Soekarno Hatta No.10, Rajabasa, Bandar Lampung, 35144

3 Jurusan Teknik Pertanian Universitas Lampung JI. Prof. Dr. Sumantri Brojonegoro No. 1 Bandar Lampung, 35145

* Penulis Korespondensi:

E-mail: diding.sughandy@fp.unila.ac.id
}

\section{PENDAHULUAN}

Menurut ICO (2020), Indonesia tercatat sebagai produsen kopi ke-4 terbesar dunia setelah Brazil, Vietnam, dan Kolombia. Di Indonesia, kopi merupakan salah satu produk penting dan bernilai ekonomi tinggi di sektor perkebunan dan menyumbang devisa sebesar USD 469.4 juta di tahun 2017 (Kemenperin 2018). Perkebunan kopi tersebar dari Aceh hingga Papua dengan Lampung sebagai penyumbang 
terbesar kedua dengan kontribusi sebesar 14,80\% produksi nasional dengan produksi mencapai 0,12 juta ton/tahun (Direktorat Jenderal Perkebunan 2018). Tiga daerah utama penghasil kopi di Lampung meliputi Kabupaten Lampung Barat, Tanggamus, dan Way Kanan dengan produksi utama kopi varietas Robusta.

Lampung, tepatnya di daerah Tanggamus, juga menjadi salah satu sentra penghasil kopi Codot, yaitu kopi yang dihasilkan dari biji kopi yang telah dimakan oleh hewan Codot (Cynopterus brachyotis). Kopi ini merupakan salah satu jenis kopi yang produksinya sangat terbatas. Secara umum, proses produksi kopi Codot dimulai dengan pemilihan buah kopi yang masak sempurna oleh hewan Codot yang memiliki indra penciuman yang sangat sensitif. Hewan Codot kemudian memakan bagian kulit kopi yang masak tersebut dan memuntahkan bijinya. Biji kopi inilah yang kemudian dikumpulkan secara hati-hati oleh petani untuk diproses lebih lanjut menjadi kopi bubuk Codot yang memiliki cita rasa spesial dan pada saat ini menjadi salah satu produk unggulan Kabupaten Tanggamus dengan harga jual yang lebih tinggi dibandingkan kopi biasa. Sebagian besar kopi Codot diproses melalui pengolahan biji semi-dry atau disebut juga proses honey.

Secara umum pada bentuk kopi bubuk, kopi Codot murni dan campuran terlihat sulit dibedakan sehingga terjadi potensi pemalsuan dan pengoplosan kopi Codot. Beberapa metode analisis berbasis instrumen pada saat ini telah banyak digunakan untuk uji keaslian kopi bubuk, seperti menggunakan metode HPLC (high performance of liquid chromatography) (Domingues et al. 2014), NIR spectroscopy (Moser et al. 2015), Raman spectroscopy (Wermelinger et al. 2011), NMR (nuclear magnetic resonance) spectroscopy (Defernez et al. 2017), metabolomik (Putri et al. 2019; Ongo et al. 2020), e-nose dan e-tongue (Dong et al. 2017), dan fluorescence spectroscopy (Botelho et al. 2017; Suhandy \& Yulia 2018). Secara umum, metode analisis berbasis instrumen tersebut memiliki kelebihan dibandingkan metode konvensional, yaitu menghasilkan pengukuran yang lebih cepat, akurat, dan konsisten. Meskipun akurat, sebagian besar metode tersebut membutuhkan instrumentasi yang cukup mahal (seperti HPLC, fluorescence, NIR, NMR, dan Raman spectroscopy), membutuhkan keahlian khusus untuk menjalankannya (seperti HPLC, Raman, dan NMR spectroscopy), melibatkan proses persiapan sampel yang melelahkan (seperti HPLC) serta melibatkan bahan kimia untuk proses ekstraksinya (seperti HPLC dan fluorescence spectroscopy).

UV-vis spektroskopi merupakan salah satu metode spektroskopi di daerah panjang gelombang 190-700 $\mathrm{nm}$. Interaksi antara radiasi gelombang elektromagnetik UV-vis (ultraviolet dan sinar tampak) dengan materi dapat menyebabkan terjadinya transisi elektronik, yaitu promosi elektron dari keadaan dasar ke keadaan energi tinggi. UV-vis spektroskopi memiliki beberapa keunggulan sebagai berikut: harga spektrometer terjangkau, tersedia di banyak laboratorium standar, mudah dalam pengoperasian alat, dan proses ekstraksi sampel bisa menggunakan air distilasi (bebas bahan kimia). Teknologi UV-vis spektroskopi sesuai dikembangkan di Indonesia untuk uji keaslian produk pertanian Indonesia. Hal ini didukung dengan harga alat instrumen UV-vis spektrometer yang relatif terjangkau dan pada saat ini menjadi salah satu instrumen yang sudah banyak tersedia di laboratorium standar di Indonesia. Pada saat ini, UV-vis spektroskopi telah digunakan untuk uji keaslian kopi luwak (Suhandy \& Yulia 2017a), kopi lanang (Suhandy \& Yulia 2017b), dan beberapa kopi spesialti Indonesia (Suhandy \& Yulia 2019). Dari penelusuran pustaka, belum dilaporkan penggunaan UV-vis spektroskopi dan kemometrika untuk uji keaslian kopi Codot asal Lampung. Lebih khusus, aspek kebaruan penelitian ini adalah penggunaan UV-vis spektroskopi untuk uji keaslian kopi Codot asal Lampung, yaitu membedakan kopi Codot murni dari kopi Codot campuran, baik secara kualitatif maupun kuantitatif. Uji keaslian dilakukan secara kualitatif, yaitu membedakan kopi Codot murni dari kopi campuran menggunakan metode PCA (principal component analysis) dan LDA (linear dis-criminant analysis). Secara kuantitatif dilakukan dengan cara menghitung persentase campuran kopi Codot menggunakan metode regresi PLS (partial least squares). Aspek kebaruan juga terlihat dari persentase pencampuran yang digunakan pada penelitian ini. Dari penelusuran pustaka, persentase campuran yang digunakan pada publikasi sebelumnya adalah bervariasi. Misalnya pada riset penggunaan metode high performance liquid chromatography (HPLC) dan kemometrika untuk kuantifikasi pencampuran kopi dengan ampas kopi digunakan persentase campuran sebesar 5-60\% (Cheah \& Fang 2020). FT-MIR spectroscopy dan kemometrika digunakan untuk identifikasi dan kuantifikasi pencampuran kopi. Riset ini menggunakan beberapa bahan bukan kopi sebagai bahan pencampur, seperti jagung, kacang kedelai, dan beras dengan persentase campuran sebesar 1-30\% (Flores-Valdez et al. 2020). Sementara itu, Nunez et al. (2021) menggunakan persentase campuran $0-100 \%$ pada studi kuantifikasi pencampuran kopi menggunakan metode high-performance liquid chromatography with ultraviolet and fluorescence detection (HPLC-UVFLD) dan kemometrika. Sementara itu, penelitian ini bertujuan untuk mengevaluasi penggunaan UV-vis spektroskopi dan kemometrika untuk uji keaslian kopi Codot murni dan kopi Codot campuran yang dicampur dengan kopi biasa dengan variasi persentase campuran sebesar $10-60 \%$.

\section{METODE PENELITIAN}

\section{Sampel kopi Codot dan kopi biasa}

Sampel kopi Codot dan kopi biasa dengan varietas Robusta diperoleh dari Kelompok Tani Wanita Hutan (KTWH) Himawari di Desa Margoyoso, Kecamatan Sumberejo, Kabupaten Tanggamus, Provinsi Lampung 
dan secara geografis berada pada kordinat $5^{\circ} 22^{\prime} 47.2^{\prime \prime}$ LS 10441' 8" BT. Semua sampel kopi, baik kopi Codot maupun kopi biasa, disangrai pada kondisi yang sama $\left(200^{\circ} \mathrm{C}\right.$ selama 20 menit menggunakan alat sangrai portabel). Proses pengecilan ukuran sampel kopi dilakukan dengan cara menggiling biji kopi sangrai menggunakan mesin coffee grinder (Sayota tipe SCG 178). Untuk mendapatkan sampel kopi bubuk yang seragam, kopi bubuk diayak dengan menggunakan ayakan Tyler Meinzer /I dengan ukuran mesh 50 (ukuran partikel 0,29 mm). Sebanyak 330 sampel kopi Codot murni (KM) dan kopi Codot campuran (KC) (kopi Codot yang dicampur kopi biasa) disiapkan dalam penelitian ini yang secara lengkap dideskripsikan di Tabel 1. Secara visual seperti terlihat di Gambar 1, cukup sulit untuk membedakan kopi Codot murni (0\%) dari kopi Codot campuran (10-60\%) di mana secara visual warna kopi Codot murni dan campuran sangat identik.

\section{Metode Ekstraksi Kopi}

Sampel kopi bubuk Codot murni dan campuran (masing-masing sampel dengan bobot $1 \mathrm{~g}$, seperti dapat dilihat di Tabel 1 kemudian diekstraksi dengan mengacu ke metode Suhandy dan Yulia (2018) menggunakan $50 \mathrm{~mL}$ air distilasi dengan suhu $98^{\circ} \mathrm{C}$ dan diaduk menggunakan pengaduk magnetik selama 10 menit. Setelah itu, larutan kopi disaring menggunakan kertas saring (Whatman No. 40) dan hasil saringan diaduk menggunakan pengaduk magnetik selama 5 menit. Hasil saringan kemudian diencerkan meng- gunakan air distilasi dengan perbandingan 1:20 (mL:mL).

\section{Metode Pengambilan Data Spektra UV-Vis}

Sampel yang diencerkan kemudian diambil sebanyak $3 \mathrm{~mL}$ dan diteteskan ke dalam kuvet standar $10 \mathrm{~mm}$ berbahan kuarsa dan diambil spektranya menggunakan UV-vis spektrometer (Genesys ${ }^{\mathrm{TM}} 10 \mathrm{~S}$ UV-Vis, Thermo Scientific, USA) pada panjang gelombang 190-1100 nm dengan interval $1 \mathrm{~nm}$. Spektrometer ini merupakan spektrometer dual beam dan memiliki beberapa komponen penting, di antaranya sumber cahaya (light source) berbahan lampu xenon, monokromator, pembagi berkas cahaya (beam splitter), detektor berbahan dual silicon photodiodes, dan tempat sampel (sample holder) sebanyak 6 buah (5 untuk larutan sampel dan 1 untuk larutan standar atau referensi). Prinsip kerja spektrometer ini secara umum adalah sebagai berikut: berkas cahaya polikromatik dari lampu xenon masuk ke dalam monokromator dan diubah menjadi cahaya monokromatik. Cahaya monokromatik kemudian dibagi menjadi dua berkas cahaya, satu bagian menuju ke larutan sampel dan satu bagian lagi menuju larutan standar atau referensi. Berkas cahaya yang telah melewati sampel dan referensi kemudian diteruskan ke detektor. Data transmitan ( $\mathrm{T}$ ) diperoleh dengan membandingkan nilai intensitas cahaya yang diteruskan di sampel dan di referensi, kemudian ditransformasi menjadi nilai absorbans (A). Nilai absorbans ini yang kemudian dianalisis lebih lanjut. Untuk data spektra referensi digunakan air distilasi.

Tabel 1 Deskripsi sampel kopi Codot murni dan kopi Codot campuran yang digunakan dalam penelitian

\begin{tabular}{rccc}
\hline Kode sampel & Kopi Codot $(\mathrm{g})$ & Kopi biasa $(\mathrm{g})$ & Jumlah sampel \\
\hline KM1-150 & 1,0 & 0,0 & 150 \\
KC151-180 & 0,9 & 0,1 & 30 \\
KC181-210 & 0,8 & 0,2 & 30 \\
KC211-240 & 0,7 & 0,3 & 30 \\
KC241-270 & 0,6 & 0,4 & 30 \\
KC271-300 & 0,5 & 0,5 & 30 \\
KC301-330 & 0,4 & 0,6 & 30 \\
\hline
\end{tabular}

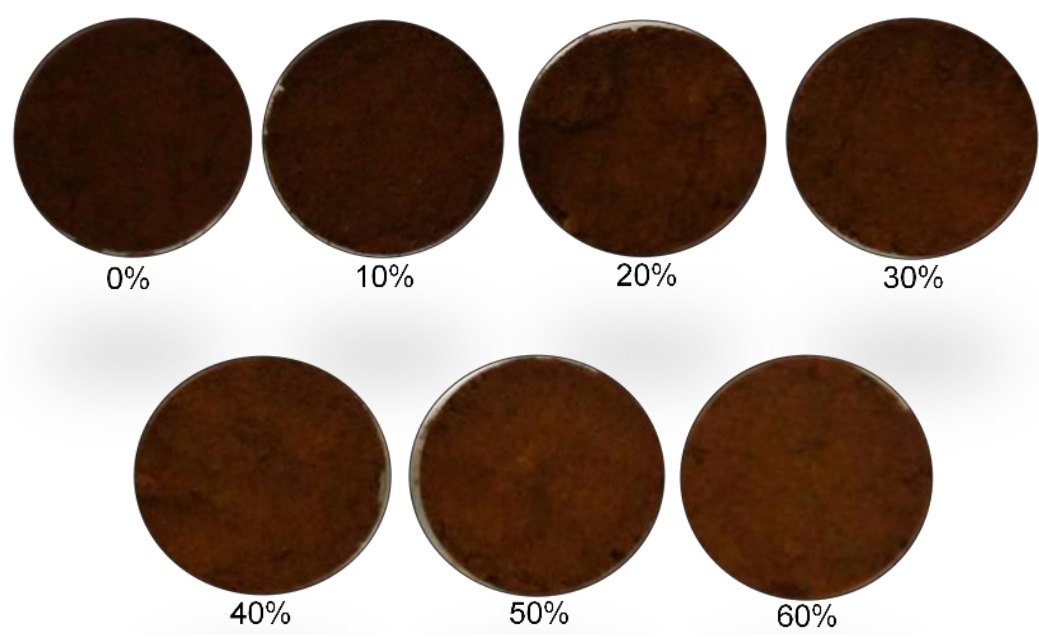

Gambar 1 Tampilan kopi Codot murni (0\%) dan kopi Codot campuran (10-60\%) 


\section{Metode Kemometrika untuk Uji Keaslian Kopi Codot Lampung}

Spektra original adalah spektra yang langsung diperoleh dari hasil pengambilan spektra yang dimodifikasi menggunakan 3 algoritma secara sekaligus, yaitu: Savitzky-Golay smoothing dengan 5 segmen (SGS), standard normal variate (SNV), dan SavitzkyGolay first derivative dengan 5 segmen dan ordo 2 (SG 1d). SG smoothing secara umum dapat digunakan untuk menghilangkan noise frekuensi tinggi (highfrequency noise) dari data spektra sekaligus memperbaiki nilai rasio noise dan sinyal (SNR atau signal to noise ratio) (Savitzky \& Golay 1964; Suhandy \& Yulia 2020). Metode SNV efektif untuk memperbaiki spektra dengan cara mengeliminasi deviasi spektra akibat perbedaan ukuran partikel sampel dan efek hamburan atau scatter pada spektra (Barnes et al. 1989; Suhandy \& Yulia 2020). Sementara itu, metode SG first derivative atau turunan pertama SG secara efektif menghilangkan pengaruh perbedaan baseline yang muncul akibat perbedaan densitas dan ukuran sampel (Savitzky \& Golay 1964; Suhandy \& Yulia 2020).

Analisis kemometrika pertama yang digunakan adalah analisis PCA (principal component analysis). PCA merupakan salah satu metode proyeksi yang digunakan untuk mencari variabel baru bernama principal components (PCs) yang jauh lebih sederhana (biasanya di bawah 10 variabel) yang merupakan kombinasi linear dari variabel asli yang kompleks (biasanya ratusan hingga ribuan variabel yang saling berkorelasi). PCs ini dipilih sedemikian rupa sehingga PC pertama (PC1) memiliki nilai varian terbesar, sedangkan $\mathrm{PC}$ berikutnya (PC2) tegak lurus terhadap PC1 (menjamin tidak terjadinya korelasi antara PC1 dan PC2), dan memiliki varian terbesar berikutnya (PC1 > PC2). Kemudian PC2 > PC3, PC3 > PC4, dan seterusnya (Granato et al. 2017). Luaran pertama dinyatakan dalam bentuk plot skor sampel nilai PC1 dan PC2 untuk melihat potensi pengelompokan sampel ke dalam kelas kopi Codot murni dan kopi Codot campuran. Luaran kedua adalah plot nilai $x$ loadings versus panjang gelombang. Identifikasi panjang gelombang dengan nilai $x$-loadings tinggi dilakukan dan hasilnya digunakan sebagai dasar penentuan variabel input untuk analisis kemometrika berikutnya, yaitu klasifikasi kopi Codot murni dan kopi Codot campuran menggunakan metode klasifikasi LDA (linear discriminant analysis).

Hasil klasifikasi kopi Codot murni dan campuran dinyatakan dalam bentuk matriks konfusi, seperti yang disajikan di Tabel 2 (Cheah \& Fang 2020). TP atau true positive adalah sampel kopi Codot murni yang diklasifikasikan sebagai kopi Codot murni. TN atau true negative adalah sampel kopi Codot campuran yang diklasifikasikan sebagai kopi Codot campuran. FP atau false positive adalah sampel kopi Codot campuran yang diklasifikasikan sebagai kopi Codot murni. FN atau false negative adalah sampel kopi Codot murni yang diklasifikasikan sebagai kopi Codot campuran.
Berdasarkan matriks konfusi tersebut dapat dihitung empat parameter berikut, yaitu sensitivitas (SEN), spesifisitas (SPEC), presisi (PREC), dan akurasi (ACC) dengan rentang nilai antara $0-100 \%$ yang dihitung dengan persamaan 1 sampai 4 sebagai berikut (Luna et al. 2016):

$$
\begin{array}{r}
\operatorname{SEN}(\%)=\frac{\mathrm{TP}}{\mathrm{TP}+\mathrm{FN}} \times 100 \%(1) \\
\operatorname{SPEC}(\%)=\frac{\mathrm{TN}}{\mathrm{TN}+\mathrm{FP}} \times 100 \%(2) \\
\operatorname{PREC}(\%)=\frac{\mathrm{TP}}{\mathrm{TP}+\mathrm{FP}} \times 100 \%(3) \\
\operatorname{ACC}(\%)=\frac{\mathrm{TP}+\mathrm{TN}}{\mathrm{TP}+\mathrm{TN}+\mathrm{FP}+\mathrm{FN}} \times 100 \%
\end{array}
$$

Analisis kemometrika berikutnya adalah penentuan persentase campuran kopi Codot yang dilakukan menggunakan metode regresi PLS (partial least square). Evaluasi model regresi PLS dilakukan dengan mengacu kepada Suhandy et al. (2013) menggunakan parameter koefisien determinasi $\left(R^{2}\right)$ baik untuk kalibrasi $\left(R^{2}\right.$ kal), validasi $\left(R^{2}\right.$ val), dan prediksi $\left(R^{2}{ }_{\text {pred }}\right)$. Kemudian nilai standard error baik untuk kalibrasi (root mean squared error of calibration atau RMSEC), validasi (root mean squared error of validation atau RMSEV), dan prediksi (root mean squared error of prediction atau RMSEP). Nilai RPD atau ratio prediction to deviation untuk kalibrasi $\left(R P D_{k a l}\right)$ dan prediksi $\left(R P D_{\text {pred }}\right)$ dihitung menggunakan persamaan 5 dan 6 (Araújo et al. 2020). Di mana $S D_{\text {val }}$ merupakan standar deviasi sampel validasi dan $S D_{\text {pred }}$ merupakan standar deviasi sampel prediksi. Nilai RPD antara 1,5 dan 2,0 menunjukkan model regresi mampu membedakan antara persentase campuran level rendah dan tinggi, RPD antara 2,0 dan 2,5 menunjukkan model regresi yang diperoleh dapat digunakan untuk memprediksi persentase campuran, dan nilai RPD antara 2,5 dan 3,0 menunjukkan model regresi yang dibangun dapat digunakan untuk memprediksi persentase campuran dengan sangat baik sekali (excellent) (Mariani et al. 2015).

$$
\begin{aligned}
\mathrm{RPD}_{\text {kal }} & =\frac{\mathrm{SD}_{\mathrm{val}}}{\mathrm{RMSEV}}(5) \\
\mathrm{RPD}_{\text {pred }} & =\frac{\text { SDpred }}{\operatorname{RMSEP}}(6)
\end{aligned}
$$

Semua perhitungan analisis kemometrika termasuk modifikasi spektra, PCA, LDA, dan regresi PLS dilakukan menggunakan perangkat lunak pengolah data spektra The Unscrambler versi 9,8 dan versi 10,4 (CAMO AS, Norwegia).

Tabel 2 Matriks konfusi untuk klasifikasi kopi Codot murni dan campuran

\begin{tabular}{ccc}
\hline & \multicolumn{2}{c}{ Sampel aktual } \\
\hline Sampel prediksi & Campuran & Murni \\
\hline Campuran & TN & FN \\
Murni & FP & TP \\
\hline
\end{tabular}




\section{HASIL DAN PEMBAHASAN}

\section{Spektra Kopi Codot Murni dan Campuran}

Gambar 2 menunjukkan plot spektra original rataan kopi Codot murni dan campuran pada panjang gelombang 190-1100 nm. Intensitas absorbans di panjang gelombang $450-1100 \mathrm{~nm}$ sangat kecil atau mendekati 0 sehingga tidak memberikan informasi terkait perbedaan kopi Codot murni dan campuran. Pada panjang gelombang sekitar $190-250 \mathrm{~nm}$, nilai intensitas absorbans sekitar 2,50-3,80 yang setara dengan nilai transmitans sebesar $0,02 \%-0,32 \%$. Artinya persentase cahaya yang diteruskan ke detektor sangat kecil sekali karena sebagian besar cahaya diblok atau diserap oleh sampel sehingga menghasilkan nilai absorbans yang sangat tinggi dan berpotensi noisy sehingga panjang gelombang $190-250 \mathrm{~nm}$ tidak dilibatkan lagi dalam perhitungan. Analisis selanjutnya fokus pada panjang gelombang $250-450 \mathrm{~nm}$.

Gambar 3 menunjukkan plot spektra modifikasi rataan di panjang gelombang $250-450 \mathrm{~nm}$. Spektra modifikasi diperoleh dengan mentransformasi spektra original menggunakan tiga algoritma pengolah data spektra secara sekaligus, yaitu: Savitzky-Golay smoothing dengan 5 segmen (SGS), standard normal variate (SNV), dan Savitzky-Golay first derivative dengan 5 segmen dan 2 ordo (SG 1d). Salah satu kelemahan UV-vis spektroskopi adalah nilai SNR atau signal noise to ratio yang rendah dan hal ini dapat diperbaiki salah satunya dengan menggunakan algoritma SNV. Kemudian, algoritma SG 1d dapat digunakan untuk melakukan koreksi atas adanya perbedaan baseline pada spektra kopi Codot murni dan campuran. Selain itu, perbedaan antara spektra kopi Codot murni dan campuran sangatlah kecil, terutama untuk persentase campuran level rendah (10-20\%). Algoritma SG 1d efektif digunakan untuk memperjelas perbedaan antara spektra kopi Codot murni dan campuran. Hanya saja, sebagai konse- kuensi dari penggunaan algoritma SG 1d adalah munculnya noise. Hal ini dapat dihindari jika data spektra diperhalus (smoothed) terlebih dahulu dengan algoritma SGS sebelum dilakukan proses derivasi. Dengan demikian, di dalam penelitian ini tiga buah algoritma yang digunakan untuk memperbaiki spektra secara berurutan adalah sebagai berikut: SGS, SNV, dan SG 1d. Beberapa panjang gelombang memiliki nilai absorbans yang tinggi, yaitu di panjang gelombang $270 \mathrm{~nm}, 290 \mathrm{~nm}, 315 \mathrm{~nm}$, dan $345 \mathrm{~nm}$. Keempat panjang gelombang tersebut berkorelasi dengan absorbans beberapa senyawa penting dalam kopi. Menurut Souto et al. (2015), secara umum panjang gelombang di interval $239-405 \mathrm{~nm}$ berkorelasi dengan transisi elektronik $n \rightarrow \pi^{*}$ dari kromofor $\mathrm{C}=0$ yang terdapat pada senyawa trigonelline, kafein, asam kafeik (caffeic acid), dan melanoidins.

Secara umum, kopi hijau (green bean) kaya dengan beberapa senyawa bioaktif dari kelompok alkaloid dan fenolik (Yisak et al. 2018; Jamali et al. 2021). Dua senyawa alkaloid penting dengan kandungan paling tinggi pada kopi hijau adalah kafein dan trigonelline. Sementara itu, asam kafeik (3,4-dihydroxy cinnamic acid) merupakan salah satu senyawa fenolik penting kopi yang memiliki fitur manfaat medis seperti bahan anti-virus dan anti-karsinogenik (Jamali et al. 2021). Pada saat proses penyangraian berlangsung, senyawa trigonelline sebagian besar berkurang dan diubah menjadi senyawa nicotinic acid melalui proses pirolisis (Jeszka-Skowron et al. 2020), sedangkan kafein jumlahnya menyusut drastis seiring dengan peningkatan level sangrai melalui proses reaksi Maillard (Hecimovic et al. 2011). Semakin intensif proses sangrai (seperti dark roasting) maka kandungan kafein semakin berkurang. Selama proses sangrai kopi, proses pirolisis juga menghasilkan senyawa penting lain, yaitu melanoidins yang merupakan senyawa utama pembentuk warna dan aroma kopi sangrai (Ripper et al. 2020). Proses sangrai pada penelitian ini berlangsung pada suhu $200^{\circ} \mathrm{C}$ selama 20 menit yang

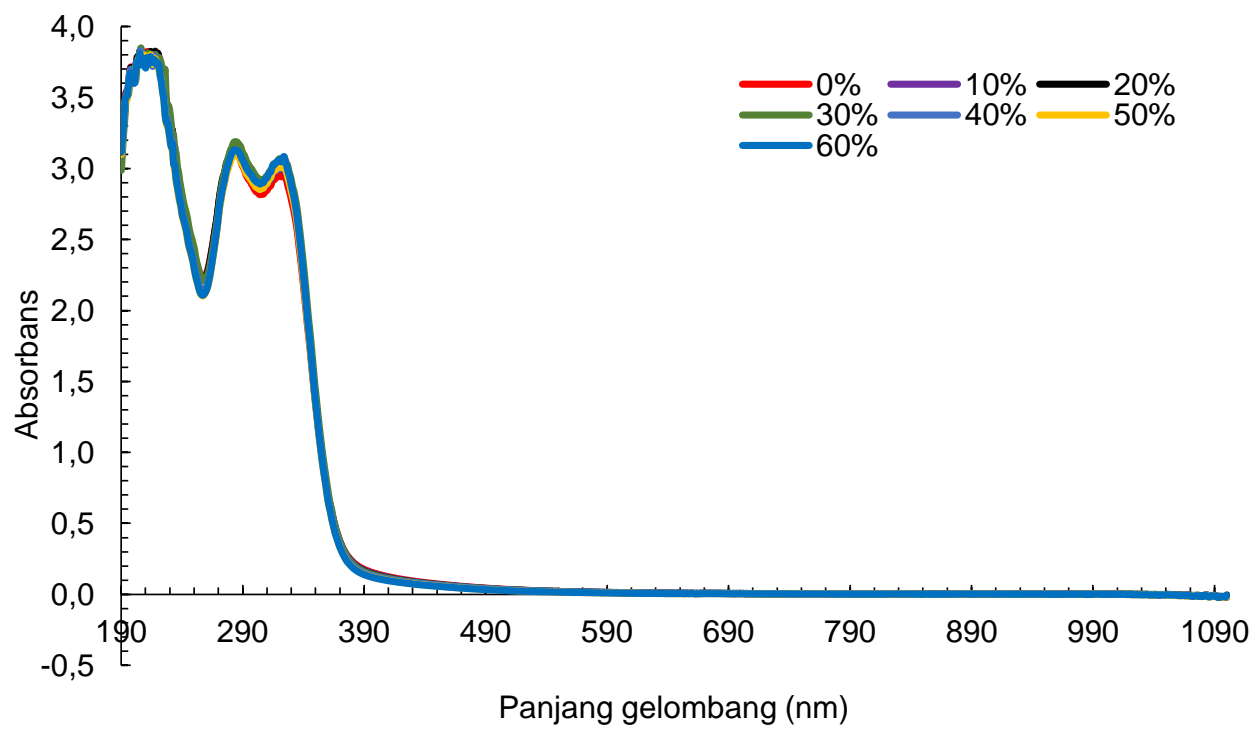

Gambar 2 Spektra original rataan kopi Codot murni dan campuran pada panjang gelombang $190-100 \mathrm{~nm}$ 


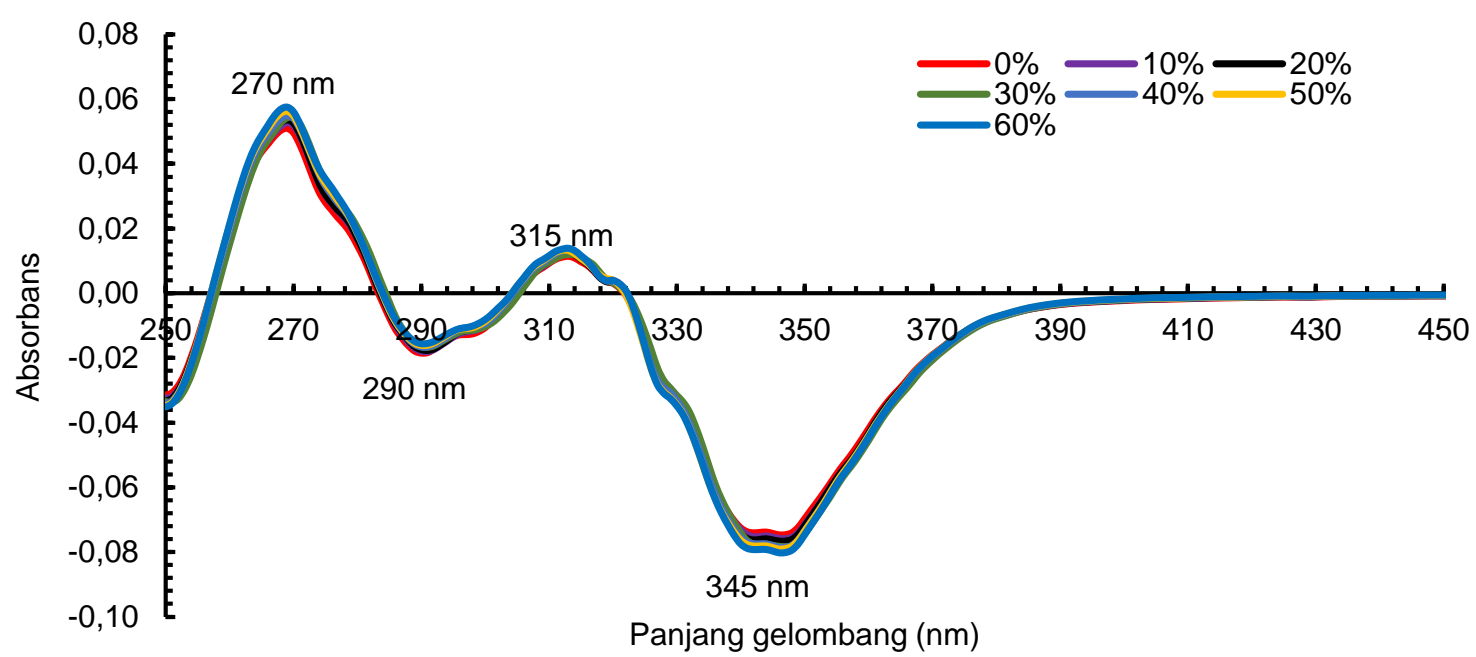

Gambar 3 Spektra modifikasi rataan kopi Codot murni dan campuran pada panjang gelombang 250-450 nm

merupakan proses sangrai medium yang masih mempertahankan sejumlah besar kandungan kafein, trigonelline, dan asam kafeik. Secara khusus, panjang gelombang 272-275 nm berkorelasi dengan puncak absorbans senyawa trigonelline kemudian panjang gelombang 276-280 nm berkorelasi dengan senyawa kafein, dan panjang gelombang 320-325 nm berkorelasi dengan senyawa asam kafeik (caffeic acid). Penelitian sebelumnya menunjukkan daerah panjang gelombang 250-450 nm memiliki kontribusi yang signifikan dalam uji keaslian beberapa kopi spesialti asal Indonesia (Suhandy \& Yulia 2017a; Suhandy \& Yulia 2017b).

\section{Hasil Perhitungan PCA}

Gambar 4 merupakan plot skor 2 PCs pertama (PC1 dan PC2) hasil analisis PCA untuk 150 sampel kopi Codot murni (0\%) dan 180 sampel kopi Codot campuran dengan tiga level campuran, yaitu level

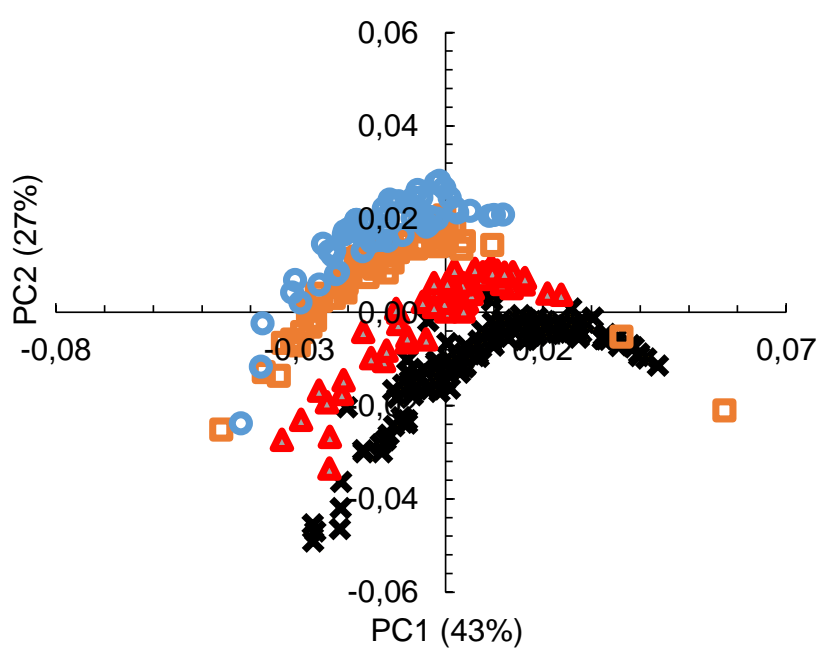

XKopi Codot Murni (campuran 0\%)

$\triangle$ Kopi Codot Campuran Level Rendah (10-20\%)

-Kopi Codot Campuran Level Sedang (30-40\%)

-Kopi Codot Campuran Level Tinggi (50-60\%)

Gambar 4 Plot skor PC1 dan PC2 untuk analisis PCA menggunakan spektra modifikasi di panjang gelombang 250-450 nm rendah (10-20\%), level sedang (30-40\%), dan level tinggi (50-60\%). Visualisasi hasil perhitungan PCA salah satunya adalah plot nilai skor dari setiap PCs (principal component). Secara umum, visualisasi ini biasanya melibatkan dua nilai PCs pertama (PC1 dan PC2). Visualisasi dikatakan cukup baik jika kedua PCs tersebut secara kumulatif mampu menjelaskan $70 \%$ atau lebih varian data spektra (Nurcahyo 2015). PC1 dan PC2 secara total dapat menjelaskan $70 \%$ varian data spektra. Secara kumulatif 10 PCs pertama mampu menjelaskan 93\% varian data spektra seperti ditunjukkan di Tabel 3.

Dari Gambar 4 dapat dilihat bahwa kopi Codot murni dan campuran dapat dibedakan di sepanjang PC1 dan PC2 di mana sampel kopi Codot semakin tidak murni (semakin besar persentase campurannya) maka skor PC semakin ke arah kiri atas (PC1 semakin negatif atau PC1 < 0 dan PC2 semakin positif atau PC2 $>0$ ). Plot nilai $x$-loadings hasil analisis PCA ditunjukkan di Gambar 5 yang memperlihatkan kontribusi setiap panjang gelombang dalam proses pemisahan sampel kopi Codot murni dan kopi Codot campuran untuk PC1, PC2, dan PC3 yang menjelaskan total $79 \%$ varian data spektra. Sebuah panjang gelombang dengan nilai absolut $x$-loadings tinggi memiliki kontribusi penting pada proses pemisahan sampel kopi Codot murni dari kopi Codot campuran. Dari Gambar 5 dapat

Tabel 3 Nilai kumulatif 10 PCs pertama hasil analisis PCA spektra modifikasi di panjang gelombang 250-450 $\mathrm{nm}$

\begin{tabular}{lc}
\hline PCs & Kumulatif total varian (\%) \\
\hline PC1 & 43 \\
PC2 & 70 \\
PC3 & 79 \\
PC4 & 83 \\
PC5 & 86 \\
PC6 & 88 \\
PC7 & 90 \\
PC8 & 91 \\
PC9 & 92 \\
PC10 & 93 \\
\hline
\end{tabular}




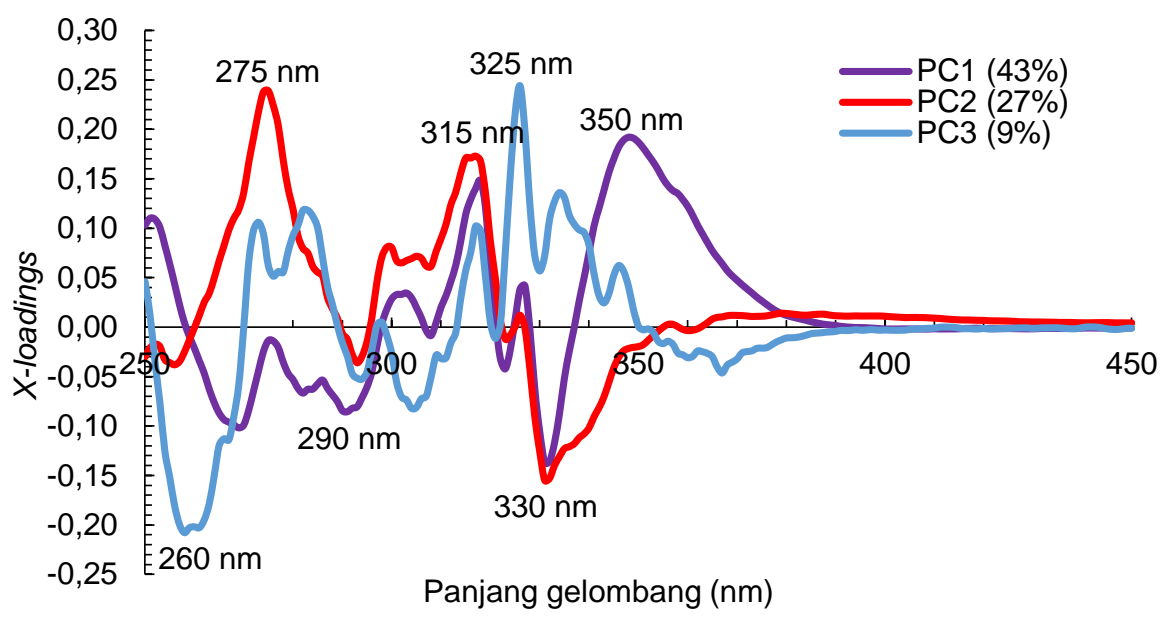

Gambar 5 Plot panjang gelombang dan nilai $x$-loadings analisis PCA menggunakan spektra modifikasi di panjang gelombang 250-450 nm

diidentifikasi beberapa panjang gelombang dengan nilai $x$-loadings tinggi (baik positif maupun negatif). Panjang gelombang dengan nilai $x$-loadings positif teridentifikasi di empat panjang gelombang, yaitu 275 $\mathrm{nm}, 315 \mathrm{~nm}, 325 \mathrm{~nm}$, dan $350 \mathrm{~nm}$ dan semuanya memiliki korelasi yang positif antara nilai PC (principal component) dan variabel panjang gelombang. Panjang gelombang dengan nilai $x$-loadings negatif teridentifikasi di tiga panjang gelombang, yaitu $260 \mathrm{~nm}, 290$ $\mathrm{nm}$, dan $330 \mathrm{~nm}$ dan berkorelasi negatif dengan nilai PC. Tujuh panjang gelombang tersebut berkorelasi dengan absorbans beberapa senyawa penting kopi, seperti trigonelline, kafein, asam kafeik (caffeic acid), dan melanoidins (Souto et al. 2015; Suhandy \& Yulia 2017a). Panjang gelombang $260 \mathrm{~nm}, 275 \mathrm{~nm}, 290 \mathrm{~nm}$, $315 \mathrm{~nm}, 325 \mathrm{~nm}, 330 \mathrm{~nm}$, dan $350 \mathrm{~nm}$ kemudian digunakan sebagai variabel input pada perhitungan LDA untuk klasifikasi kopi Codot murni dan kopi Codot campuran.

\section{Klasifikasi Kopi Codot Murni dan Campuran Menggunakan Metode LDA \\ Klasifikasi secara terbimbing (supervised} classification) kopi Codot murni dan campuran dilakukan dengan menggunakan metode LDA. Sampel kopi Codot murni dan campuran dibagi secara acak ke dalam tiga kelompok, yaitu kalibrasi, validasi, dan prediksi seperti terlihat di Tabel 4.

Pengembangan model klasifikasi LDA dilakukan dengan menggunakan sampel kalibrasi dan validasi (total 275 sampel) dengan menggunakan 7 variabel panjang gelombang sebagai input. Tujuh variabel tersebut adalah data spektra modifikasi di panjang gelombang hasil dari analisis $x$-loadings: $260 \mathrm{~nm}, 275$ nm, 290 nm, 315 nm, 325 nm, 330 nm, dan 350 nm. Gambar 6 menunjukkan hasil pengembangan model LDA dengan metode linear dan diperoleh nilai akurasi sebesar 90,91\%. Dari 125 sampel kopi Codot murni, terdapat 4 sampel yang diklasifikasikan salah sebagai kopi Codot campuran. Sementara itu, dari 150 sampel kopi Codot campuran, terdapat 21 sampel yang diklasifikasikan salah sebagai kopi Codot murni.
Untuk mengevaluasi kemampuan model klasifikasi LDA yang diperoleh maka dilakukan klasifikasi atas sampel prediksi (total 55 sampel) dan hasilnya ditunjukkan dalam bentuk matriks konfusi, seperti

Tabel 4 Pembagian sampel kopi Codot murni dan campuran untuk klasifikasi menggunakan metode LDA

\begin{tabular}{cccc}
\hline Sampel & Kalibrasi & Validasi & Prediksi \\
\hline Murni & 75 & 50 & 25 \\
Campuran & 90 & 60 & 30 \\
Total & 165 & 110 & 55 \\
\hline
\end{tabular}

Tabel 5 Matriks konfusi hasil klasifikasi kopi Codot murni dan campuran menggunakan model LDA untuk sampel prediksi

\begin{tabular}{ccc}
\hline & \multicolumn{2}{c}{ Sampel aktual } \\
\hline Sampel prediksi & Campuran & Murni \\
\hline Campuran & $\mathrm{TN}=23$ & $\mathrm{FN}=0$ \\
Murni & $\mathrm{FP}=7$ & $\mathrm{TP}=25$ \\
\hline
\end{tabular}

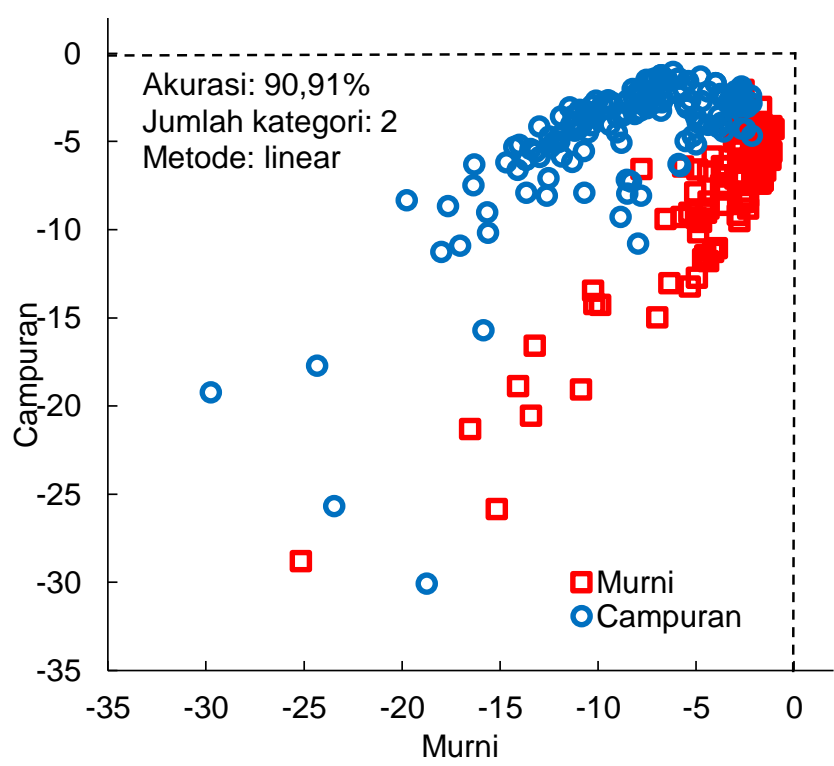

Gambar 6 Model LDA yang dibangun menggunakan spektra modifikasi dengan variabel input tujuh panjang gelombang 
disajikan di Tabel 5. Semua sampel murni (25 sampel) berhasil diklasifikasikan secara benar sebagai kopi Codot murni. Dari 30 sampel kopi Codot campuran, terdapat 7 sampel kopi Codot campuran yang salah diklasifikasikan sebagai kopi Codot murni. Dengan demikian, berdasarkan matriks konfusi yang diperoleh di Tabel 5 dan dengan menggunakan persamaan 2 sampai 5 maka diperoleh sensitivitas (SEN) sebesar $100 \%$, spesifisitas (SPEC) sebesar $76,67 \%$, presisi (PREC) sebesar 78,13\%, dan akurasi (ACC) sebesar $87,27 \%$. Pada penelitian sebelumnya, Souto et al. (2015) menggunakan metode LDA untuk membedakan kopi murni dari kopi campuran (yang dicampur sekam kopi) dengan sensitivitas, spesifisitas, dan akurasi sebesar $100 \%$. Charlton et al. (2002) menggunakan metode NMR dan LDA untuk membedakan kopi instan dari tiga produsen yang berbeda dan diperoleh nilai akurasi sebesar $99 \%$. Studi terbaru menunjukkan penggunaan Raman spectroscopy dan metode LDA mampu mengklasifikasikan kopi berdasarkan kultivarnya dengan nilai akurasi sebesar $100 \%$ (Luna et al. 2019).

\section{Penentuan Persentase Campuran Kopi Codot Menggunakan Metode Regresi PLS}

Sampel yang digunakan hanya sampel kopi Codot campuran (10-60\%) sebanyak total 180 sampel yang dibagi ke dalam sampel kalibrasi, validasi, dan prediksi secara acak seperti yang ditunjukkan di Tabel 6. Nilai standar deviasi (SD) untuk sampel kalibrasi, validasi, dan prediksi secara berurutan adalah $S D_{\text {kal }}=17,2 \%$, $S D_{\text {val }}=17,2 \%$, dan $S D_{\text {pred }}=17,4 \%$. Penentuan persentase campuran dilakukan dengan membangun model regresi PLS menggunakan sampel kalibrasi dan validasi.

Gambar 7 dan 8 menunjukkan plot persentase kopi Codot campuran aktual dan prediksi untuk model regresi yang dibangun pada panjang gelombang 250-450 nm menggunakan data spektra modifikasi. Nilai koefisien determinasi untuk kalibrasi dan validasi sangat tinggi, yaitu $R^{2}$ kal $=0,99$ dan $R^{2}$ val $=0,98$. Nilai $R P D_{k a l}$ yang diperoleh lebih dari 2,5 $\left(R P D_{\text {kal }}=6,47\right)$ menunjukkan model regresi yang dibangun dapat digunakan untuk proses uji keaslian kopi Codot, yaitu dalam penentuan persentase kopi Codot campuran (Assis et al. 2017). Model regresi PLS yang dibangun kemudian digunakan untuk memprediksi persentase kopi Codot campuran untuk sampel prediksi dan hasilnya ditunjukkan di Gambar 9. Koefisien determinasi yang diperoleh sangat tinggi $\left(R^{2}\right.$ pred $\left.=0,98\right)$. Prediksi juga menghasilkan nilai $R P D_{\text {pred }}=6,49$ yang menunjukkan hasil prediksi yang sangat baik (excellent).

\section{KESIMPULAN}

Penelitian ini telah berhasil memperlihatkan potensi penggunaan metode UV-vis spektroskopi dan kemometrika untuk uji keaslian kopi Codot Lampung. Secara kualitatif, hasil analisis PCA dan LDA menunjukkan
Tabel 6 Pembagian sampel kopi Codot campuran ke dalam sampel kalibrasi, validasi, dan prediksi

\begin{tabular}{lccc}
\hline \multicolumn{1}{c}{ Item } & Kalibrasi & Validasi & Prediksi \\
\hline Jumlah & 90 & 60 & 30 \\
Maksimum & $60 \%$ & $60 \%$ & $60 \%$ \\
Minimum & $10 \%$ & $10 \%$ & $10 \%$ \\
Rataan & $35 \%$ & $35 \%$ & $35 \%$ \\
SD & $17,2 \%$ & $17,2 \%$ & $17,4 \%$ \\
\hline
\end{tabular}

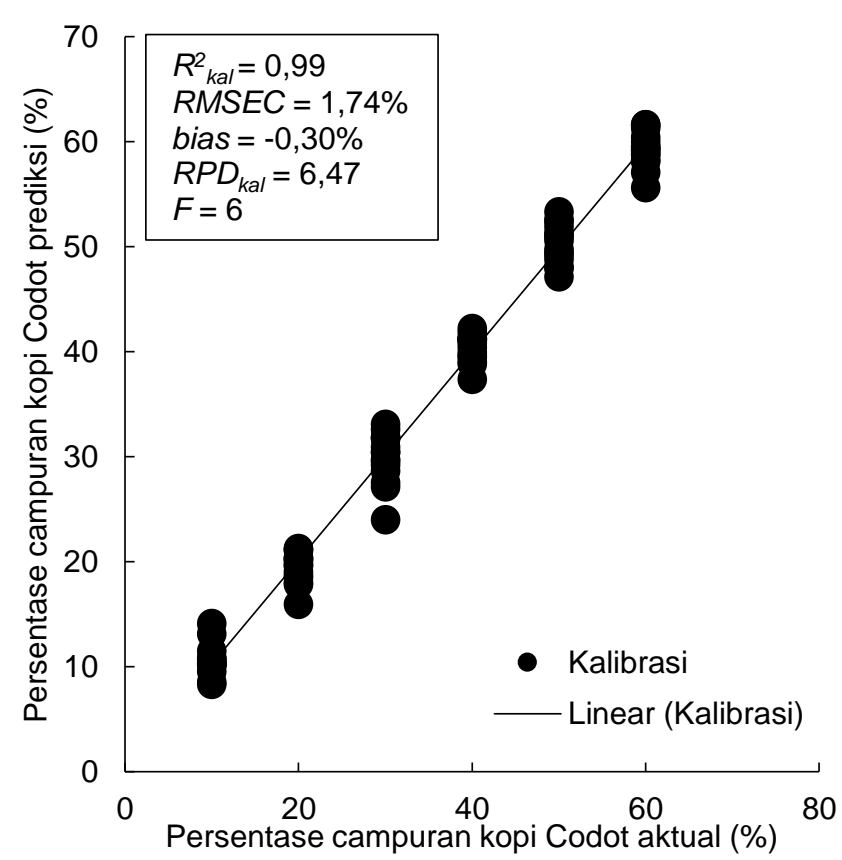

Gambar 7 Plot persentase campuran kopi Codot aktual dan prediksi pada model kalibrasi yang dibangun menggunakan spektra modifikasi pada panjang gelombang $250-450 \mathrm{~nm}$

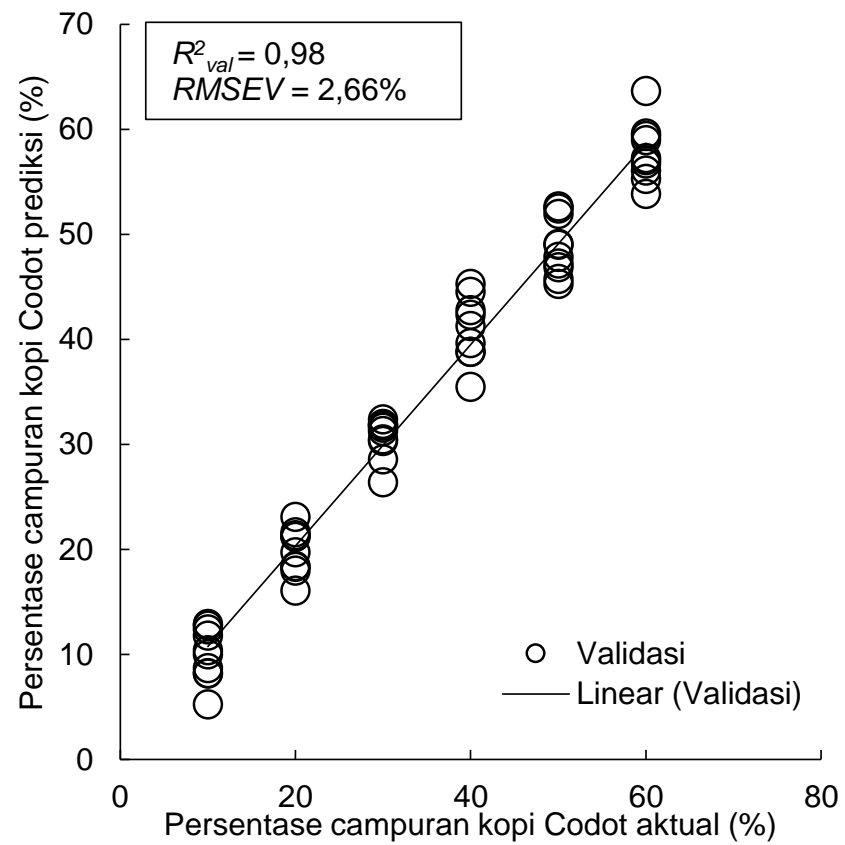

Gambar 8 Plot persentase campuran kopi Codot aktual dan prediksi pada tahap validasi yang dibangun menggunakan spektra modifikasi pada panjang gelombang $250-450 \mathrm{~nm}$ 


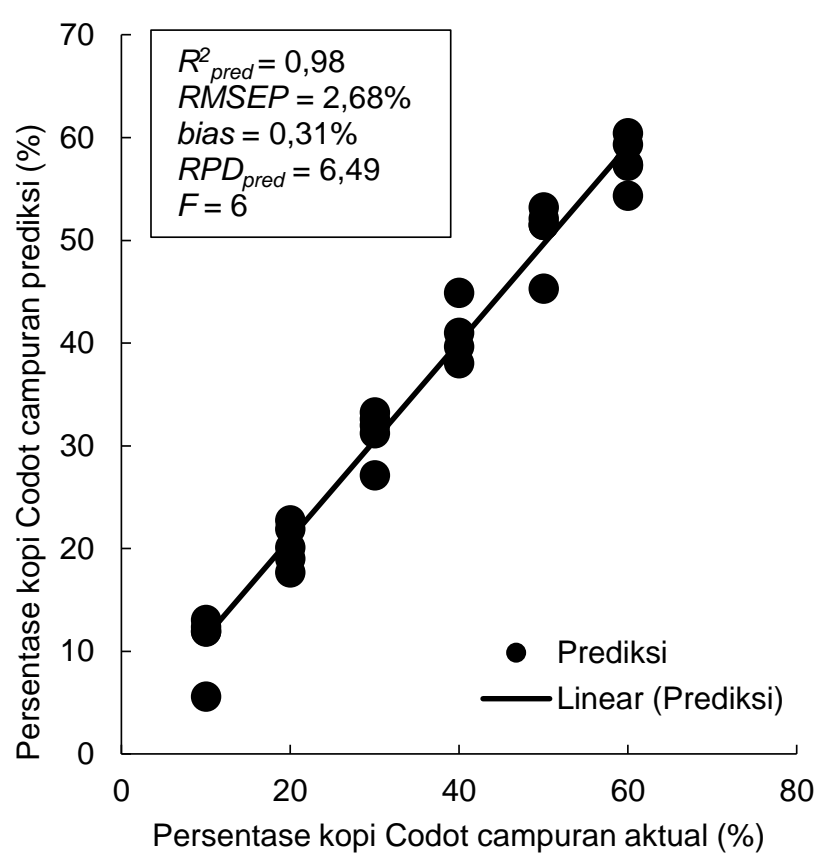

Gambar 9 Plot persentase campuran kopi Codot aktual dan prediksi hasil prediksi menggunakan model regresi PLS

sampel kopi Codot murni dan kopi Codot campuran dapat dibedakan dan klasifikasi LDA menghasilkan nilai akurasi klasifikasi sebesar 87,27\%. Secara kuantitatif, model regresi PLS yang dibangun mampu memprediksi persentase kopi Codot campuran dengan nilai RPD yang sangat baik (di atas 3 ) baik untuk kalibrasi maupun prediksi. Dengan demikian, dapat disimpulkan, UV-vis spektroskopi dan kemometrika tepat digunakan untuk studi uji keaslian kopi bubuk Codot Lampung dan ke depan dapat diajukan sebagai salah satu metode analisis untuk membangun sistem sertifikasi kopi Codot Lampung.

\section{UCAPAN TERIMA KASIH}

Penulis mengucapkan terima kasih kepada Kemendikbudristek/BRIN atas dukungan pendanaan penelitian ini melalui hibah skema Penelitian Kerjasama Antar Perguruan Tinggi (PKPT) tahun 2020-2022 (No. 92/E4.1/AK.04.PT/2021 dan No. 378.1/PL15.8/PT/2021). Penulis juga mengucapkan terima kasih kepada semua pihak yang telah membantu pelaksanaan penelitian ini.

\section{DAFTAR PUSTAKA}

Araújo CS, Macedo LL, Vimercati WC, Ferreira A, Prezotti LC, Saraiva SH. 2020. Determination of $\mathrm{pH}$ and acidity in green coffee by near infrared spectroscopy and multivariate regression. Journal of the Science of Food and Agriculture. 100(6): 2488-2493. https://doi.org/10.1002/jsfa. 10270

Assis C, Oliveira LS, Sena MM. 2017. Variable selection applied to the development of a robust method for the quantification of coffee blends using mid infrared spectroscopy. Food Analytical Methods. 11: 578-588. https://doi.org/10.1007/s12 161-017-1027-7

Barnes RJ, Dhanoa MS, Lister SJ. 1989. Standard normal variate transformation and de-trending of near-infrared diffuse reflectance spectra. Applied Spectroscopy. 43(5): 772-777. https://doi.org/10.1 366/0003702894202201

Botelho BG, Oliveira LS, Franca AS. 2017. Fluorescence spectroscopy as tool for the geographical discrimination of coffees produced in different regions of Minas Gerais State in Brazil. Food Control. 77: 25-31. https://doi:10.1016/j.food cont.2017.01.020

Charlton AJ, Farrington WHH, Brereton P. 2002. Application of ${ }^{1} \mathrm{H}$ NMR and multivariate statistics for screening complex mixtures: quality control and authenticity of instant coffee. Journal of Agricultural and Food Chemistry. 50(11): 3098-3103. https:// doi.org/10.1021/jf011539z

Cheah WL, Fang M. 2020. HPLC-based chemometric analysis for coffee adulteration. Foods. 9(7): 880-891. https://doi.org/10.3390/foods9070880

Defernez $M$, Wren $E$, Watson $A D$, Gunning $Y$, Colquhoun IJ, Le Gall G, Williamson D, Kemsley EK. 2017. Low-field ${ }^{1} \mathrm{H}$ NMR spectroscopy for distinguishing between arabica and robusta ground roast coffees. Food Chemistry. 216: 106-113. https://doi.org/10.1016/j.foodchem.2016.08.028

Direktorat Jenderal Perkebunan. 2018. Statistik Perkebunan Indonesia 2017-2019: Kopi. Jakarta (ID): Kementerian Pertanian.

Domingues DS, Pauli ED, de Abreu JEM, Massura FW, Cristiano V, Santos MJ, Nixdorf SL. 2014. Detection of roasted and ground coffee adulteration by HPLC by amperometric and by post-column derivatization uv-vis detection. Food Chemistry. 146: 353-362. https://doi.org/10.1016/j.foodchem.-2013.09.066

Dong W, Zhao J, Hu R, Dong Y, Tan L. 2017. Differentiation of Chinese robusta coffees according to species, using a combined electronic nose and tongue, with the aid of chemometrics. Food Chemistry. 229: 743-751. https://doi:10.1016/j. foodchem.2017.02.149

Flores-Valdez M, Meza-Márquez OG, Osorio-Revilla G, Gallardo-Velázquez T. 2020. Identification and quantification of adulterants in coffee (Coffea 
arabica L.) using FT-MIR spectroscopy coupled with chemometrics. Foods. 9: 851. http://dx.doi.org/10. 3390/foods 9070851

Granato D, Santos JS, Escher GB, Ferreira BL, Maggio RM. 2017. Use of principal component analysis (PCA) and hierarchical cluster analysis (HCA) for multivariate association between bioactive compounds and functional properties in foods: A critical perspective. Trends in Food Science \& Technology. 72: 83-90. https://doi:10.1016/j.tifs.20 17.12.006

Hecimovic I, Belscak-Cvitanovic A, Horzic D, Komes D. 2011. Comparative study of polyphenols and caffeine in different coffee varieties affected by the degree of roasting. Food Chemistry. 129(3): 991-1000. https://doi:10.1016/j.foodchem.2011.05 .059

ICO. 2020. World Coffee Production. [Internet]. [diunduh 2021 Jan 8]. Tersedia pada: http://www. ico.org/prices/po-production.pdf.

Jamali N, Mostafavi-Pour Z, Zal F, Kasraeian M, Poordast T, Nejabat N. 2021. Antioxidant ameliorative effect of caffeic acid on the ectopic endometrial cells separated from patients with endometriosis. Taiwanese Journal of Obstetrics and Gynecology. 60(2): 216-220. https://doi.org/10.10 16/j.tjog.2020.12.003

Jeszka-Skowron M, Frankowski R, Zgoła-Grześkowiak A. 2020. Comparison of methylxantines, trigonelline, nicotinic acid and nicotinamide contents in brews of green and processed Arabica and Robusta coffee beans - Influence of steaming, decaffeination and roasting processes on coffee beans. LWT - Food Science and Technology. 125: 109344. https://doi.org/10.1016/j.Iwt.2020.109344

[Kemenperin] Kementerian Perindustrian. 2018. Naik 10 persen ekspor kopi olahan nasional tembus USD 469 Juta. [Internet]. [diunduh 2021 Jan 8]. Tersedia pada: http://www.kemenperin.go.id/artikel/19194/ Naik-10-Persen,-Ekspor-Kopi-Olahan-Nas-ional-Te mbus-USD-469-Juta

Luna AS, da Silva AP, da Silva CS, Lima ICA, de Gois JS. 2019. Chemometric methods for classification of clonal varieties of green coffee using raman spectroscopy and direct sample analysis. Journal of Food Composition and Analysis. 76: 44-50. https:// doi.org/10.1016/j.jfca.2018.12.001

Luna AS, Pinho JSA, Machado LC. 2016. Discrimination of adulterants in UHT milk samples by NIRS coupled with supervision discrimination techniques. Analytical Methods. 8(39): 7204-7208. https://doi.org/10.1039/C6AY01351A

Mariani NCT, Teixeira GHA, de Lima KMG, Morgenstern TB, Nardini V, Júnior LCC. 2015. NIRS and iSPA-PLS for predicting total anthocyanin content in jaboticaba fruit. Food Chemistry. 174: 643-648. https://doi.org/10.1016/j.foodchem.2014. 11.008

Moser JK, Singh M, Rennick KA, Bakota EL, Jham GN, Liu SX, Vaughn SF. 2015. Detection of corn adulteration in brazilian coffee (coffea arabica) by tocopherol profiling and NIR spectroscopy. Journal of Agricultural and Food Chemistry. 63(49): 10662-10668. https://doi.org/10.1021/acs.jafc.5b0 4777

Nunez N, Saurina J, Nunez O. 2021. Authenticity assessment and fraud quantitation of coffee adulterated with chicory, barley, and flours by untargeted HPLC-UV-FLD fingerprinting and chemometrics. Foods. 10: 840. https://doi.org/10.3 390/foods 10040840

Nurcahyo B. 2015. Identifikasi dan autentikasi meniran (Phyllanthus niruri) menggunakan kombinasi spektrum ultraviolet-tampak dan kemometrika. [Skripsi]. Bogor (ID): Institut Pertanian Bogor.

Ongo EA, Montevecchi G, Antonelli A, Sberveglieri V, Sevilla III F. 2020. Metabolomics fingerprint of Philippine coffee by SPME-GC-MS for geographical and varietal classification. Food Research International. 134: 109227. https://doi:10.1016/j.fo odres.2020.109227

Putri SP, Irifune T, Yusianto, Fukusaki E. 2019. GC/MS based metabolite profiling of Indonesian specialty coffee from different species and geographical origin. Metabolomics. 15: 126. https://doi.org/10.10 07/s11306-019-1591-5

Ripper B, Kaiser CR, Perrone D. 2020. Use of NMR techniques to investigate the changes on the chemical composition of coffee melanoidins. Journal of Food Composition and Analysis. 87:103399. https://doi:10.1016/j.jfca.2019.103399

Savitzky A, Golay MJE. 1964. Smoothing and differentiation of data by simplified least-squares procedures. Analytical Chemistry. 36(8): 1627-1639. https://doi.org/10.1021/ac60214a047

Souto UTCP, Barbosa MF, Dantas HV, de Pontes AS, Lyra WS, Diniz PHGD, de Araújo MCU, da Silva EC. 2015. Identification of adulteration in ground roasted coffees using uv-vis spectroscopy and SPA-LDA. LWT - Food Science and Technology. 63(2): 1037-1041. https://doi.org/10.1016/j.Iwt.2015.04.003

Suhandy D, Yulia M, Ogawa Y, Kondo N. 2013. Prediction of I-ascorbic acid using ftir-atr terahertz spectroscopy combined with interval partial least squares (iPLS) regression. Engineering in Agriculture, Environment and Food. 6(3): 111-117. https://doi.org/10.11165/eaef.6.111

Suhandy D, Yulia M. 2017a. The use of partial least square regression and spectral data in uv-visible 
region for quantification of adulteration in indonesian palm civet coffee. International Journal of Food Science. 2017: 1-7. https://doi.org/10.115 $5 / 2017 / 6274178$

Suhandy D, Yulia M. 2017b. Peaberry coffee discrimination using UV-Vis spectroscopy combined with SIMCA and PLS-DA. International Journal of Food Properties. 20(sup1): S331-S339. https://doi.org/10.1080/10942912.2017.1296861

Suhandy D, Yulia M. 2018. Discrimination of several Indonesian specialty coffees using fluorescence spectroscopy combined with SIMCA method. IOP Conference Series: Materials Science and Engineering. 334: 012059. https://doi.org/10.1088/ 1757-899X/334/1/012059

Suhandy D, Yulia M. 2019. Klasifikasi kopi bubuk spesialti kalosi dan toraja menggunakan uv-visible spectroscopy dan metode PLS-DA. Jurnal IImu
Pertanian Indonesia. 24(1): 73-81. https://doi.org/1 0.18343/jipi.24.1.73

Suhandy D, Yulia M. 2020. Teknologi near infrared spectroscopy portabel untuk kuantifikasi atribut mutu buah-buahan. Yogyakarta (ID): Graha IImu.

Wermelinger T, D'Ambrosio L, Klopprogge B, Yeretzian C. 2011. Quantification of the robusta fraction in a coffee blend via raman spectroscopy: proof of principle. Journal of Agricultural and Food Chemistry. 59(17): 9074-9079. https://doi.org/10.1 021/jf201918a

Yisak H, Redi-Abshiro M, Chandravanshi BS. 2018. Selective determination of caffeine and trigonelline in aqueous extract of green coffee beans by FTMIR-ATR spectroscopy. Vibrational Spectroscopy. 97: 33-38. https://doi:10.1016/j.vibspec.2018.05.0 03 